\title{
THE ROLE OF KENYAN UNIVERSITIES IN NATIONAL DEVELOPMENT
}

\author{
George Odhiambo ${ }^{1}$
}

The University of Sydney, Australia

\begin{abstract}
The contribution of university education to sustainable development of society has become one of the most important activities of higher education institutions. After 55 years of independence, it is time to take a critical look at the role of university education in nation building in Kenya. Since independence, access and difficulties of maintaining standards of quality and efficiency with marginal available resources- more recently highlighted by a commission on higher education report- have been some of the key challenges in university education and these have impacted on the sector's contribution to the country's development. Embracing secondary data sources, the purpose of this paper is to explore the contribution that university institutions have played in Kenyan development using a framework of human capital theory. The paper concludes that longterm economic growth can only be achieved through investment in a highly skilled workforce and university education is particularly critical in this regard.
\end{abstract}

Keywords: Development; University Education; Job Market; Kenya; Information and Communication Technologies

\section{Introduction}

The mission of most universities comprises a moral obligation to contribute to the intellectual, cultural, and economic betterment of society in general. For public universities, this is also a legal obligation, directed in part at the betterment of conditions in their country and region. To meet this obligation, universities must strive to contribute to the discovery of new knowledge, and to instil an appreciation of the value of the pursuit of knowledge. In doing so, universities contribute to both the intellectual vitality and the economic wellbeing of society; produce educated citizens; train the next generation of leaders; and actively engage in public service activities that bring knowledge and research findings to the attention of citizens and industry (Hirsch \& Weber, 1999). The purpose of this paper is to critically examine the contribution that university institutions have played in Kenyan development-specifically economic growth and employment against a backdrop of profound challenges for university transformation and learning more recently highlighted by a commission on higher education report. This examination is important

\footnotetext{
${ }^{1}$ Correspondence: A35 - Education Building, The University of Sydney, NSW 2006 Australia; Email: george.odhiambo@sydney.edu.au
} 
because of universities' potential as catalysts for development as well as generation of productivity gains that fuel economic growth.

Despite the rapid growth in university education in Kenya, there are serious concerns about the ability of Kenya's universities to produce the kind of graduates who can drive the country forward. Concerns about university graduate's employment and the kind of skills they bring to workplace as well as their contribution to the country's development goals has been widespread (e.g. British Council, 2014; Wanzala, 2015). This has led to a continued debate on the quality and relevance of university education in Kenya (see Odhiambo, 2011). This paper critically analyses the challenges facing Kenyan universities and their implications for the country's development goals. The analysis aims to either spark or guide more discussion on key issues influencing the development of universities in Kenya as well as the role played by universities in the country's development.

Kruss et al. (2015) argued that in general, university education and development has not been a priority of global policy or research funding in recent years. For many years, those responsible for funding education in Africa including donor institutions have tended to place more emphasis on the development of primary and secondary schooling with universities largely ignored. For example, the 2000 Dakar summit on 'Education for All' advocated only for primary education as a driver of a number of social welfare and ignored university education. Earlier, Tilak (2005) argued that part of the reason for the lack of attention to university education within development initiatives lies in the shortage of empirical evidence that it affects economic growth and poverty eradication.

The analysis in this paper is done through the use of secondary data sources and a framework of Human Capital Theory. Education has been retheorized under Human Capital Theory as primarily an economic device. The human capital theory developed in 1960 by Theodore Schulz examined the benefit of education for individuals and society. A key strategy in determining economic performance has been to employ a conception of individuals as human capital and various economic metaphors such as "technological change," "research," "innovation," "productivity," "education," and "competitiveness." Economic considerations per se in the past, however, have not determined education. Since its formulation, Human Capital Theory has developed into one of the most powerful theories in modern economics. The growth of the concept of the "knowledge economy" in the last few years has also afforded it a further degree of importance because of the strong connections it sees between education and training and economic growth. Where economic activity becomes focused on knowledge and on intellectual rather than physical labour, the importance of education to that economy becomes more crucial. Human Capital Theory thus lays considerable stress on the education of individuals as the key means by which the individual accrues material advantage and by which the economy progresses. In a simple equation, the more and better education individuals possess, the better their returns in financial rewards and the more the national economy flourishes.

Human Capital Theory has thus promoted education to a key instrumental role in boosting economic growth. The better the investment made by individuals in education, the better they and the economy will do. This elevated status, however, is not without its problematic aspects. There is a risk of education being narrowed to economic goals, of the broader aims and purposes of education being submerged, and of the person being reduced merely to "human capital," not as a life to be lived, but as mere economic potential to be exploited (Gillies, 2011).

Human Capital Theory has been controversial from its earliest days. There has been concern at seeing education viewed in such narrow economic terms and omitting broader and richer purposes and practices. Whole areas of the curriculum such as the expressive arts, and the humanities in general, struggle for perceived relevance when bald economic purposes are given exclusive attention. Similarly, conceptualizing humans as 
mere capital goods seems excessively reductivist, omitting much of what it means to be a person (Gillies, 2017).

In general, researchers like Easterly (2014) have created further controversy with regard to development by strongly arguing that there are no silver bullets for promoting economic development and that the best hope is to support economic, political, and personal freedom worldwide. However, a critical analysis of such arguments is beyond the scope of this paper.

Regarding university education, there has been a lot of debate around its economic growth and poverty eradication benefits with Friedman and Friedman (1980) originally arguing that there was no evidence that university education yields social benefits over and above the benefits that accrue to students themselves and hypothesising that university education may promote social unrest and political instability. In Africa in particular, there have been some arguments against the idea that university education is the route to development based on the contention that the greater the investment in university education, the greater the burden to the African states (Uetela, 2017).

In contrast to these views, most evidence suggests that university education is a determinant as well as a result of income and can produce public and private benefits (Bloom, Hartley \& Rosovsky, 2006; Bloom et al., 2014). There are arguments pointing to the interactions between the key variables of university expansion, growth, productivity and development with recent evidence pointing to correlations between university education and innovations (e.g. Pillay, 2011). Bloom et al. (2014) particularly argued that university education may create tax revenue, increase savings and investment and lead to a more entrepreneurial and civic society. A good example is India's leap onto the world economic stage which observers have attributed to its success in providing high quality, technical oriented university education to a significant number of its nationals.

In Kenya, university education while highly valued and acclaimed by all, currently faces great challenges with a potential impact on the sector's contribution to the country's development. In recent years, powerful forces have led to an increased societal demand for university education. While this demand has grown, the operating costs to provide these have risen and public and government support for universities has flattened and then declined over the past two decades (Odhiambo, 2011; Michubu, Nyerere \& Kyalo, 2017).

Secondary data embraced in this paper include data generated through reviews, documentary analysis as well as datasets from organisations such as Kenya Bureau of Statistics, Commission for University Education, Republic of Kenya, Institute of Economic Affairs and World Bank. Development in technology has led to a considerable increase in the number of individual-based data sources, registers, data bases, and information systems that may be of value to a research paper like this. As Thomas \& Heck (2001, p.517) argued, "Research in higher education has benefited tremendously from the increased availability of quality secondary data sets germane to our varied interests".

\section{The meaning and concept of development}

The term development has been used in a variety of contexts and often clouded with political and ideological overtones. For almost every researcher/writer, a different definition of development exists. It is not purely an economic term as many believe but a multidimensional process involving reorganisation and reorientation of entire economic as well as social systems. As such, development generally means improvement in a country's economic and social conditions.

Two general approaches to development can be distinguished (Myint, 1980 cited in Szirmai, 2015):

i. The fight against poverty- an approach focusing on the problems of widespread poverty, hunger and misery particularly in developing countries and on the 
question of what can be done in order to realise improvements of the situation in the short term.

ii. The analysis of long-term economic and social development- an approach concentrating on comparing developments in different countries, regions and historical periods in order to gain a better understanding of the factors that have long-term effects on the dynamics of socio-economic development.

A comprehensive discussion of these including the historical analysis of development philosophies is beyond the scope of this paper. However, it is important to note that both approaches are important.

Beliefs about definitions of development shape the assumptions, values, actions, processes and aims of organisations and institutions. For example, Todaro and Smith (2015) viewed development from the modernisation paradigm which sees development as a multidimensional process which involves the sustained elevation of the entire society and social system towards a better or humane life. They identify three components of development- sustenance, self-esteem and freedom. According to Todaro \& Smith (2015) sustenance is concerned with ability to meet basic needs; self-esteem is concerned with a sense of worth and self-respect and freedom is concerned with freedom from servitudeservitude to nature, ignorance, other people, misery, institutions and dogmatic beliefs especially that poverty is a predestination (Orji \& Maekae, 2013)

Another important concept we must try to explain is national development. Markovitz (1977) stressed that a developed society is the one that has succeeded in providing a source of living for the majority of its inhabitants and that in such society, premium is attached to elimination of poverty, provision of food, shelter and clothing to its members.

\section{University Education and National Development}

History shows that most African nations strove to establish at least one national university immediately after independence. The major purpose for establishing universities in these countries was, and still is, for the institutions to play a pioneering role in addressing problems of poverty, social disorganisation, low production, unemployment, hunger, illiteracy and diseases (the problems of underdevelopment) which appeared to be common on the African continent (Mosha, 1986).However, it is important to recognise that African countries differ from one another in characteristics that influence how university education may affect economic growth particularly in terms of policies, political and economic histories and geographical circumstances (Bloom et al., 2014).

The contribution of university education to a country's development is a theme that has attracted growing attention in recent years. The basic notion that university education is an important tool for creating skilled manpower is neither uncommon nor unfamiliar within the large body of education and development policy documents produced in Kenya since independence. For example, the earliest national education policy blueprint in post-independent Kenya affirmed that university education is a vital instrument for national development and nation building (Republic of Kenya, 1964). This notion was later affirmed by the World Bank funded policy document Kenya Education Sector Support Program, 2005-2010 (Republic of Kenya, 2005) as well as the report on Public University Inspection Board (Republic of Kenya, 2006) and Task Force on National Education Strategy report (Republic of Kenya, 2007) As indicated by Chege (2015, p.21), researchers are generally divided on this issue: some attribute a direct linkage between university education and development whereas others are sceptical of such a direct correlation. Universities like other knowledge institutions are increasingly expected not only to conduct education and research, but also to play an active role in the economic, social and cultural development of their regions. Arbo \& Benneworth (2007) argue that the extent to which universities are able to play this role depends on a number of 
circumstances including the characteristics of the institutions, the regions in which they are located and the policy frameworks.

Within Africa, there has been a growing interest in university education with many reports highlighting the importance of university education in affecting not just economic development and renewal but also social and political development. GyimahBrempong, Paddison \& Mitiku (2006) study concluded that 1per cent increase in the average years of university education in Africa increased the growth rate of per capita income by 0.09 per cent points per year which was three times as large as growth impact of physical capital investment. However, they noted that this could be slightly higher than the actual impact since they were unable to disentangle primary and secondary education effects.

The former UN Secretary-General Kofi Annan in an address upon receiving an honorary degree from the University of Ghana put it rather well:

I believe that the university must become a primary tool for Africa's development in the new century. Universities can help develop African expertise; they can enhance the analysis of African problems; strengthen domestic institutions; serve as a model environment for the practice of good governance, conflict resolution and respect for human rights; and enable African academics to play an active part in the global community of scholars (United Nations Information Service, 2000).

Despite the interest, most sub-Saharan African countries' university education systems struggle with inadequacy of financial resources, unmet demands, weak institutions and autocratic governments with an intolerance for academic freedom (see Stromquist, 2017). A few years ago, Makinda (2007, p.973) argued that 'Africa's poverty partly stems from the lack of strong scientific, technological and knowledge bases' and emphasised that among others, African policy makers need to define the type of knowledge their countries require and revamp their universities.

\section{University Education in Kenya}

The origins of university education in Kenya can be traced to 1947, when the colonial government came up with a plan seeking to establish a technical and commercial institute in Nairobi (Bailey, Cloete \& Pillay 2013). However, it was not until 1951 that this concept received a Royal Charter, under the name of the Royal Technical College of East Africa. The College was initially designed to provide instruction in courses leading to the Higher National Certificate offered in Britain and to prepare matriculated students for university degrees in engineering, and commercial courses not available in Makerere in Uganda (Mwiria \& Nyukuri 1994). It admitted the first students in 1956 (Bailey, Cloete \& Pillay 2013) to become the first Kenyan higher educational institution (Nyangau, 2014; Ngome, 2003) and in 1970 it became the first fully-fledged university-the University of Nairobi (Odhiambo, 2011). Before independence in 1963, education in Kenya was to a large extent governed by the philosophy that Africans required just basic technical skills to enable them to do menial jobs. University education was a preserve of the whites and a few Africans and was received from universities outside Africa. Most of the colleges in Kenya were affiliates of foreign universities like the Royal Technical College (currently University of Nairobi) which was affiliated to University of London.

After independence, the demand for university education in Kenya has continued to increase (Odhiambo, 2014; Odhiambo, 2016; Kivati, 2017). The universities are categorised into public and private- public universities were fully funded by the government and still receive most of their funding from the government although they are increasingly supplementing this with tuition fees (particularly from students on the 
so called "parallel degree programs"). "Parallel degree programs" were mainly introduced in universities for the purpose of generating money. This is the strategy of admitting full fee-paying students over and above the students who are admitted with government subsidy (see Odhiambo, 2011). Private universities on the other hand rely more on private investors although recent reforms have made it possible for their students to have access to government loans as much as students in public universities. They also have to follow rules and regulations set by the Ministry of Education. Kenya currently has 30 public universities with several constituent colleges and campuses, and 17 chartered private universities also with a number of constituent colleges (Commission for University Education, 2017a) of which about 70 per cent were established between 2012 and 2013.

Unfortunately, the universities have continued to face serious financial problems. In the past few years, they have been operating on a Sh9 billion (currently about 90M US\$) deficit, a situation which has continued to undermine their ability to offer quality education and training and to conduct research (Aduda, 2016). Even as funding drops, enrolment numbers have continued to soar.

As many researchers (e.g. Kilonzo, 2011; Mathooko \& Ogutu, 2015; Tarus, Gichoya \& Muumbo, 2015) have clearly indicated, financing of universities is becoming increasingly difficult for a number of reasons:

- The public sector is hard pressed with tasks mainly on the transfer side of the budget (e.g., attending to an aging population, health care, poverty, and foreign aid), as well as with security issues and the maintenance of public infrastructure. Consequently, the percentage share of the revenue being devoted to university education is bound to diminish.

- The private sector is less ready to finance universities without getting a service in return or without being able to influence their activities.

- The cost of providing university education and of doing research continues to grow significantly.

In spite of the financial pressures, universities have done relatively little to become more efficient or to reinvent themselves (see Aduda, 2016; Wanzala, 2018). The financial crisis has had far reaching consequences for university education including, stifling university growth, delivery of poor services, exodus of academic staff seeking better pay elsewhere, student riots, and stunted creativity and innovation. Some universities have resorted to unethical practices (to attract students and to raise the required revenue) like lowering entry requirements (for the "parallel degree" course students) and relaxing academic standards to graduate many students (see Aduda, 2016).

Others have continued to encourage the supposedly marketable courses and leave out others and, hence, limit students' choices particularly for the "parallel degree" students. For example, evidence shows that business and administration courses which have been deemed marketable have recorded the highest students' enrolment. This means that technical subjects which provide students with opportunities for working scientifically and for developing hands-on skills are largely ignored (Aduda, 2016).

Before independence, the Kenyan curriculum was technically and vocationally oriented because it provided them with skills that aimed at fitting them as labourers on farms owned by white settlers (Bogonko, 1992). Therefore, after independence as Lauglo (2005) asserts, Kenyans rushed to throw off the "shackle" of vocational, technical and practical subjects in favour of the academic education that they had previously been denied. This trend has continued as the technical subjects are being largely ignored for a number of reasons. Kenya Vision 2030 (Government of the Republic of Kenya, 2007) policy document identifies Technical and Vocational Education and Training (TVET) as the anchor of its economic pillar through science, technology and innovation to boost Kenya's industrialisation status. Ngure (2013) study indicated that in Kenya, TVET 
suffers from numerous and entrenched problems: a rigid and unresponsive curriculum; poor methods of identifying training needs; lack of stakeholders' involvement in curriculum designs; inadequate numbers of specialised staff to design and revise curriculum; poor training methods; and obsolete tools and equipment at the training institutions. It is also characterised by difficult social, political and economic aspects and multiple providers who do not necessarily follow the approved national curriculum. However, comprehensive examination of TVET in Kenya is beyond the scope of this paper.

The combination of high enrolments and low funding has hit even established universities hard. Most of the universities do not have enough academic staff; many lecturers aren't properly qualified; there are no decent teaching or learning facilities or access to innovative technology and this means that teaching often doesn't advance beyond traditional methods (see Odhiambo, 2014). The inferior academic climate has also seen a surge in academic fraud: plagiarism, fabricated references, students impersonating each other in exams and lecturers demanding money or sexual favours in exchange for passing grades (Nyangau, 2014; Munene, 2016). In probably the most dramatic case of fraud recently, the Commission for University Education cancelled five doctoral degrees awarded by a University as it emerged that the five students had only studied for six months each before receiving their doctorates (Wanzala, 2016).

Kenya's economic outlook is not as good as it should be, with stubbornly high unemployment among young people and a schooling system which is still failing to deliver good compulsory education for all. A recent review commissioned by United Kingdom's DFID (Department for International Development) (Oketch, McCowan \& Schendel, 2014) on the impact of university education on development concluded that the impact was limited by several factors particularly quality.

Another recent audit inspection report of universities in Kenya released on 16th February 2017 (Commission for University Education 2017b) also painted a gloomy picture for university education in the country.

The quality inspection focused on 13 key areas namely:

1. Student enrolment

2. Student progression

3. Quality and integrity of examinations, dissertations and research projects

4. Certification process

5. Award of degrees

6. Award of honorary degrees

7. Academic and research leaders and their qualifications

8. Appointment and promotion of academic staff

9. Measures undertaken by universities to de-ethicise the academic, non-academic staff and students to embrace diversity.

10. Allocation of funds

11. Senate approval and accreditation of programs

12. Evidence of accreditation of programs

13. Any other matters that may negatively impact on quality of University education. (Commission for University Education, 2017b).

The commission inspection highlighted a number of critical issues regarding university education in Kenya. They included:

- Abuse of Credit Accumulation and Transfer Systems (CATS)

- Some universities offered academic programs which were not approved by the University senates with evidence of duplication of programs and 'premature specialisation' at undergraduate level. 
- The process of moderation of examinations was lax in some universities leading to 'substandard examinations'.

- Most universities did not have a policy, software or mechanisms for checking plagiarism

- Some universities overruled examiners recommendations and graduated students who had been recommended for a 'Fail result' by examiners where as some approved students who had not met the minimum required instructional hours for graduation.

- There was weak security control in some universities in terms of printing, storage and sealing of certificates

- In some circumstances, there were variances between the senate approved graduation list and the final list

- In many universities, there were no clear promotion criteria for academic staff

It is increasingly clear that how to fund university education amidst rising demand for places and concerns about falling academic standards are some of the issues facing the university education system. A weak regulatory framework has not helped the situation. Due to increased higher education quality challenges, the government, through a legal mandate established by an Act of Parliament (Cap 210B) in 1985, formed the Commission for Higher Education (CHE) to oversee and enhance the quality of university education in Kenya. CHE was initially focused on the accreditation of private universities. However, its mandate later expanded to cover public universities- by which time, university growth had gone unchecked for many years. CHE was replaced by the Commission for University Education (CUE) established by an Act of Parliament, the Universities Act No. 42 of 2012. However, CUE still lacks the organisational, technical and human capacities to monitor and enforce quality compliance (Odhiambo, 2014). Professional bodies have tried to step into the gap left by the CUE's shortcomings by intervening to close university programs they claim are not up to industry standards but unfortunately, these bodies have no statutory powers and have been sued for their interventions. In 2011 for example, the Engineering Registration Board of Kenya refused to recognise the engineering degree from three leading public universities in Kenya because of poor curricula, lack of qualified lecturers and shortage of appropriate facilities. In the same year, on similar grounds, the Council of Legal Education of Kenya rejected the applications to practice law from graduates of several public and private universities in Kenya.

In 2007, the government of Kenya embarked on a new long term national planning strategy, officially known as Kenya Vision 2030 (Government of the Republic of Kenya, 2007). Vision 2030, the country's new development blue print covering the period 2008 to 2030 aims to "transform Kenya into a newly industrialising middle-income country providing a high-quality life to all its citizens by the year 2030' (Government of the Republic of Kenya, 2007, p.1). The vision is based on the economic, social and political 'pillars'. The economic pillar aims to improve the country's economic prosperity through an economic development program. The social pillar aims at social equity while the political pillar aims at creating a democratic society.

Kenya Vision 2030 strategy emphasises that Kenya should provide globally competitive quality education training and research to her citizens for development and to enhance individual wellbeing. It further emphasises the important role that university education needs to play to achieve these development goals (Chege, 2015). However, in spite of the fact that the contribution of university education is on the policy agenda, it remains far from clear what their new responsibilities will entail.

Vision 2030 has committed the country to an ambitious roadmap of development for the coming years. In line with the proposals for the new Sustainable Development Goals, the vision has been put forward with the objectives of eradicating poverty, creating 
cohesive and secure societies, and ensuring sustainable and equitable growth. While the importance of primary and secondary education in development has long been acknowledged, there is increasing recognition that without university education too, none of these goals will be achieved. It is therefore unfortunate that the university sector in the country is currently facing nothing short of a crisis. The system has been allowed to expand without corresponding resources, leading to a catastrophic drop in quality and an increasing number of poorly equipped graduates going into an already congested job market.

However, despite the rapid growth, it is interesting to note that Kenya's university education enrolment rates are still much lower than many countries as illustrated in figure 1 below:

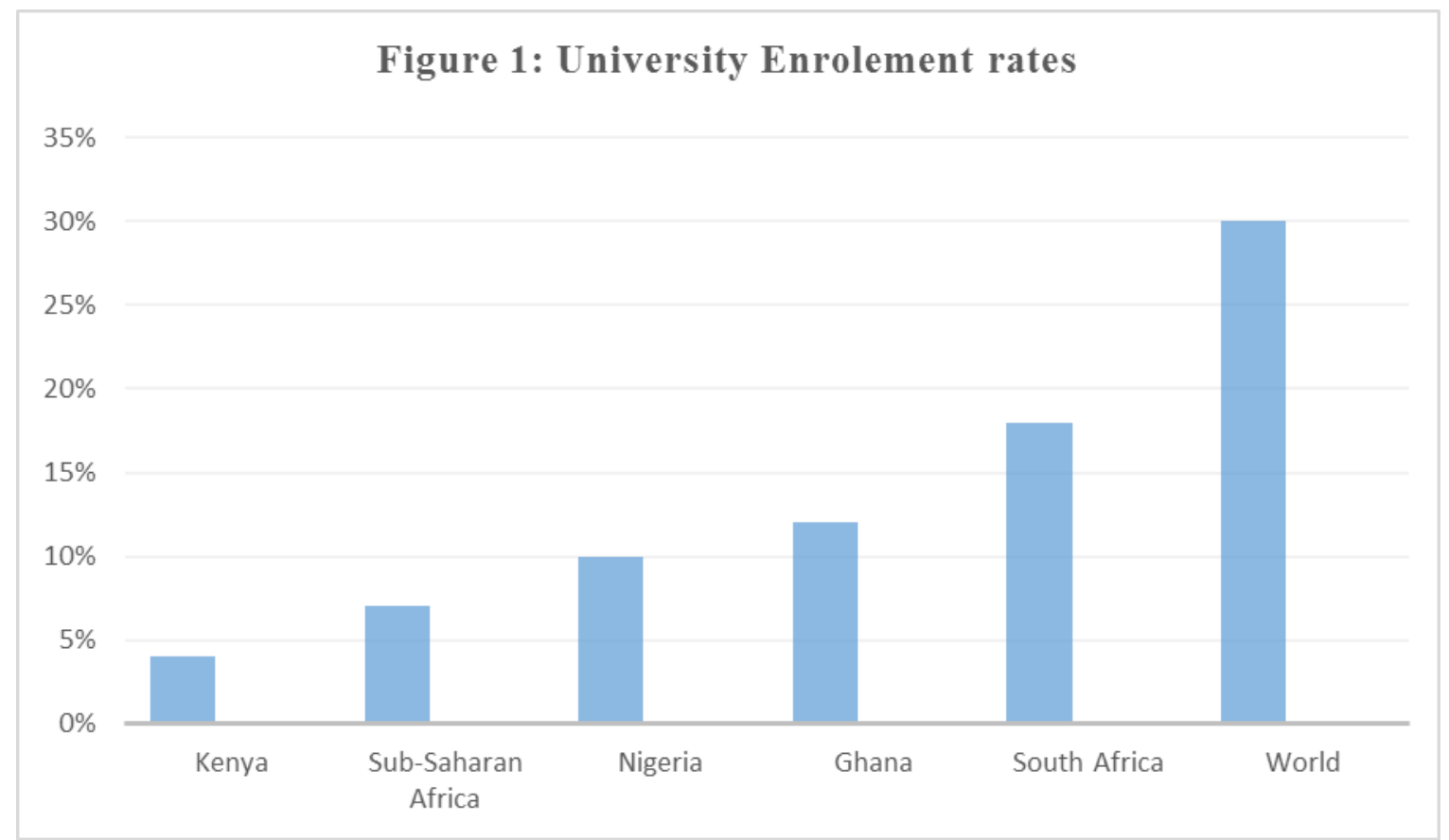

Source: British Council. (2014).

If Kenya is to realise its potential, there is need to build a stronger link between universities and the labour market to ensure graduates generate growth and a strong society. One of the key areas through which university institutions can contribute to a country's development is by improving their academic responsiveness to increasingly complex labour market needs and industry requirements. How many women and men are in employment and how productive they are at work has a lot do to with the available opportunities to acquire and maintain relevant skills.

The link between gender inequality and economic growth is a topic that is of growing interest. Gender inequality in employment in Kenya in terms of labour force participation, and wage disparities is well documented (see for example, De Giusti \& Kambhampati, 2016; Cuberes \& Teignier, 2014; Oduol et al., 2017). Although a comprehensive discussion of gender and the Kenyan workforce is beyond the scope of this paper, it is important to provide a brief review of the situation. Table 1 below clearly indicates that more need to be done in terms of Women's participation in wage employment: 
Tables 1: Distribution of Wage Employment by Gender and monthly income (Kenya Shillings- 100Ksh = about 1US\$) 2013-2016.

\begin{tabular}{|c|c|c|c|c|c|c|c|c|c|c|c|c|}
\hline \multirow{2}{*}{$\begin{array}{l}\text { Income } \\
\text { (monthly } \\
\text { groups) }\end{array}$} & \multicolumn{3}{|c|}{2013} & \multicolumn{3}{|c|}{2014} & \multicolumn{3}{|c|}{2015} & \multicolumn{3}{|c|}{2016} \\
\hline & Male & Female & Total & Male & Female & Total & Male & Female & Total & Male & Female & Total \\
\hline $0-9,999$ & 12,316 & 7,136 & 19,452 & 13,414 & 7,727 & 21,141 & 14024 & 8078 & 22,102 & 14,522 & 8,365 & 22,887 \\
\hline $15,000-19,999$ & 111,986 & 64,891 & 176,877 & 110,182 & 63,469 & 173,650 & 115,192 & 66,354 & 181,546 & 117,900 & 67,914 & 185,814 \\
\hline $20,000-24,000$ & 216,734 & 125,587 & 342,321 & 247,163 & 142,373 & 389,538 & 258,402 & 148,848 & 407,250 & 265,633 & 153,014 & 418,648 \\
\hline $25,000-24,000$ & 293,524 & 170,084 & 463,608 & 299,086 & 172,284 & 471,370 & 312,685 & 180,118 & 492,803 & 322,797 & 185,943 & 508,740 \\
\hline $30,000-49,000$ & 413,864 & 239,815 & 653,680 & 424,070 & 244,280 & 668,350 & 443,353 & 255,387 & 698,740 & 456,489 & 262,954 & 719,444 \\
\hline
\end{tabular}

Source: Kenya National Bureau of Statistics (2017).

Countries, enterprises and persons all perceive skills development as strategic, and consequently seek to step up investments in skills which can be done at university level. Equipping the workforce with the skills required for the jobs of today and those of tomorrow is a strategic concern in the national growth and development outlooks of most countries. Ultimately, each country's prosperity depends on how many of its people are in work and how productive they are, which in turn rests on the skills they have and how effectively those skills are used since skills are a foundation of decent work. Good-quality primary and secondary education, complemented by relevant vocational and university training and skills development prepare future generations for their productive lives, endowing them with the core skills that enable them to continue learning and to contribute effectively to the development of their countries.

\section{University Education Challenges and the Job Market}

One way many countries have addressed unemployment has been via supply-side policies (see Burtless, 2002; Rhoades \& Slaughter, 1997). Supply-side policies are policies which seek to increase the productivity and efficiency of the economy. They can involve interventionist supply-side policies (e.g. government spending on education) or free market supply-side policies (e.g. reduced government legislation) and are aimed at increasing aggregate supply. These policies seek to improve the job readiness of people who are unemployed or are making the transition from education to work, thereby making them more prepared to move into a job (or into a wider variety of jobs). The key elements of these policies aim to ensure participants' skill levels are raised to make them viable job applicants and to provide pathways for them into permanent employment. In general, education creates the basis for employment because the supply of labour from primary education through to the university level creates more highly skilled labour (see Bonin \& Hölzl, 2010) . Education creates the resources for employment and for growth in businesses, the public service and, thus, the economy as a whole.

International evidence demonstrates that strong university sectors are associated with stronger economies and higher standards of living. Countries with higher levels of university education attainment and higher levels of investment in university education research and development are consistently shown to have higher levels of per capita income. As universities open themselves up to the marketplace for knowledge and ideas to a greater degree than in the past, debates over university missions have been common. Although it is obvious that university graduates have enormous potential for innovation and economic development, a common question asked by researchers several times is whether Kenyan universities are able to match society's expectations as engines of innovative growth and employment, without jeopardising their main mission of educating and basic research (see Kivati, 2017). 
Since independence, the creation of employment has been one of the major economic challenges that Kenya has faced. This has therefore been a high priority in policy discourses by policy makers, academics and other Kenyan professionals. Among others, the government has undertaken to reorientate education and training systems from primary to university level to vocational and technical training areas as a means of promoting employment creation (Institute of Economic Affairs, 2010).

Although the mission of universities is to generate skills and knowledge for the labour market and not necessarily offer employment, there is little doubt that university education and employment have much to do with each other. As West (2000) argues:

employers recruit graduates; individuals seek to enhance their future careers through university education; research can lead to the formation of new industries or destruction of existing ones; and governments investing in higher education on behalf of the public - often wish to see some general economic payback.

However, although the linkages between the labour market and university education are strong, they are not straightforward, and the respective rights and obligations of university education institutions, organisations representing labour market interests and governments have been the subject of contest and debate. "Earn a university degree and get a job", formula has worked with relative success over many years but increasingly in many fields today, the formula is no longer working.

Kenya's unemployment problem dates back to immediate years after independence. Just like many other developing countries, unemployment has been identified as the country's most difficult and persistent problem (Omolo, 2012). A recent World Bank report (World Bank, 2014) estimated that in Sub-Saharan Africa in general, as many as 11 million young people will be joining the job market every year for the next decade. Another report (World Bank, 2016) indicated that unemployment and underemployment is still high in Kenya's urban areas. Statistics indicate that Kenya's unemployment rate recently stands at approximately $40 \%$, up from $12 \%$ in 2006 (Kinoti, 2016).

In the 1970-74 Development Plan, the government identified urban and rural unemployment, educated unemployment and underemployment as the key issues affecting the country (Republic of Kenya, 1969) and this has not changed much since then. The government has continued to identify high labour force growth, use of modern capitalintensive technology and attendant increase in labour productivity as causes of such unemployment (Omolo, 2012). The causes of the country's unemployment has also been linked to inadequate training and consequent lack of appropriate skills, shortage of land and other resources, rapid expansion in school enrolments, skills miss-match and ruralurban migration. One of the latest government policy documents, 'The Sector Plan for Labour, Youth and Human Resource Development Sector' (2008-2012) also identified miss-match in skills development and demand as one of the main causes of the country's unemployment.

Although international evidence demonstrates that high quality university sectors are associated with stronger economies and higher standards of living, quality is still under threat in many Kenyan universities and just like the introduction of free primary education in Kenya led to strains on infrastructure and drops in standards, the rapid expansion of the university education system in Kenya has presented similar dangers (see Odhiambo 2014). Very few graduates are gaining the skills they need to find work (see British Council, 2016) and nowhere is this quality challenge more evident than the transition to labour market. Graduate unemployment is high and employers across the country complain of the lack of basic, technical and transferable skills (British Council, 
2014; Nesoba, 2012). Although graduate unemployment figures specifically for university graduates are not easily available (British Council 2014), across 25-29 age group (the range corresponding most closely with recent graduates), the unemployment rate is $15.5 \%$ (Omolo, 2012). It is also estimated that on average, it takes a university graduate up to 5 years to secure a job in Kenya (Omolo, 2012).

There is a lack of basic statistical information relating to university quality and outcomes in Kenya. However, there is widespread concerns about the work readiness of university graduates and this is often linked to severe quality challenges the universities are facing (see Wesangula, 2014; Munene, 2016; Ndirangu \& Udoto, 2011). Expansion in the context of limited funding has placed the system under significant strain. At major public universities in Kenya, for example, there are now as many as 64 students for every academic staff (Commission for Higher Education 2013). In 2015, Inter-University Council for East Africa (IUCEA) in a shocking survey concluded that between 51 to 63 per cent of the graduates in Kenya, Uganda and Tanzanian universities were 'half-baked', 'unfit for jobs' and 'lacked job market skills' (Mungai, 2015).In many cases, lecturers lack adequate qualifications and preparation themselves and transmission based pedagogy and rote learning are commonplace (British Council, 2014). The Universities also suffer severe lack of physical facilities including buildings, laboratories and libraries.

Recently, universities have teamed up with employers to try to resolve the mismatch between skills impacted in students and the demand in the market. The objective is to network and link leaders from industry and universities for sustainability (Wanzala, 2017). The initiative, university-industry sustainability platform, was launched at a conference organised by Pan Africa Christian (PAC) University in partnership with Kenya Private Sector Alliance (KEPSA) and Visions of Hope for Africa.

\section{The Influence of Technology}

One of the most essential skills in the job market today is Information and Communication Technologies (ICTs). ICTs are widely understood to be an enabler of economic growth and overall development (UNDP 2001; Jorgenson and Vu 2016). The global economy has continued to undergo profound changes characterised by the spread of new ICTs. Many researchers have continued to argue that this digital revolution is enhancing performance of many countries because it is an important facilitator of effective knowledge sharing and integration (Luo \& Bu, 2016; Maryska, Doucek \& Kunstova, 2012) and can be ranked among the most important movements in economic history (Aissaoui 2017).

Maryska, Doucek \& Kunstova, (2012) argue that the contribution of ICTs to the growth of almost every economy represents $5 \%$ of the GDP and that to hold such portion, there is need for continuous supply of relevant qualified ICT professionals into the industry. ICTs role in the knowledge economy is therefore clear and since universities are fundamental to the creation, evaluation, maintenance and dissemination of knowledge, they could play a leading role in developing qualified ICT professionals.

Several studies highlight that the major challenge facing digital revolution in African universities is lack of adequate knowledge, skills and competencies on the human resources (Kandiri, 2012; Zaman, Shamim \& Clement, 2011; Ayere, Odera \& Agak, 2010). With the exception of South Africa, Mauritius, and most of North Africa, African universities are seriously constrained in the use of ICTs by a lack of computer stations and a lack of access to affordable high-speed Internet connectivity. Generally speaking, the capacity of African universities to lead the process of integrating ICTs in education, as has been the case in most of the developed world, is woefully inadequate.

While ICT continues to advance in western and Asian countries, African countries still experience a lag in its implementation, and that continues to widen the digital and knowledge divides. Kiptalam et.al. (2010), observed that access to ICT facilities is a major 
challenge facing most African countries, with a ratio of one computer to 150 students against the ratio of 1:15 students in the developed countries.

In Kenya, computers were introduced in the 1970 s and the Internet became available in 1993 (Ford 2007). According to Tarus (2011), implementation of e-learning is still at the infancy stage in most Kenyan public universities due to many challenges related to implementation. These challenges range from technological to organisational and pedagogical. The barriers to effective utilisation of ICTs in universities included absence of reward systems, lack of policies, poor support and limited financial resources.

Kenya's Vision 2030 (Government of the Republic of Kenya, 2007) provides a vision for the Kenyan education sector as a whole and the university education sector in particular. There are indications in the vision that the education and training sub-sector requires addressing some challenges in vision planning (Ndung'u, Thugge \& Otieno, 2011). One of the areas mentioned is mainstreaming ICTs at all levels of education and training by ensuring that policy and curriculum delivery is well integrated at all levels through ICTs. This underlines the importance with which the government of Kenya holds ICTs as an enabler of education delivery, management, policy and national development. Kenyan universities are being compelled by the government within this framework to introduce ICT qualifying courses 'to have globally competitive quality education, training and research for sustainable development' (NESC, 2007).

In the past, it was thought that low-labour technologies such as ICTs were not relevant in countries like Kenya where manual labour was in abundant supply. For countries struggling with the basic needs of life, including water, electricity and literacy, raising standards of living seemed more crucial than the adoption of ICTs. Disagreement existed over the priority given to ICTs in relation to other development initiatives in a country. There is now wide consensus, however, that ICTs provide opportunities to reduce social and economic disparity and to support the creation of efficient and transparent administration mechanisms. The impact of ICTs as a driver of development is profound because it creates opportunities across all segments of the economy and society (Sanou, 2011). Much more work is therefore needed with regard to ICT policies and initiatives in Kenya particularly in terms of the government's active engagement with universities so that ICT becomes part of innovation development. It is clear that Kenya has been less successful in catching up with other countries in the development of technological capabilities.

\section{Conclusion: Pathway to Change}

In today's world, knowledge has become the coin of the realm, determining the wealth of nations and powerful forces are driving an increasing societal demand for university education services. For many years, universities played an important role in political consultancy in many countries, but from the 1980's there has also been a focus on research as a source of innovation and realignment (Arbo \& Benneworth, 2007) and on creating closer ties between knowledge institutions, trade and industry.

As knowledge and educated people become key strategic priorities, our societies have become more dependent upon those social institutions such as colleges and universities that create these critical resources. However, in Kenya there is a growing concern about the capacity of the existing universities to serve these changing and growing social needs. For example, it is clear that Kenyan universities need an enhanced understanding of how they can contribute to the changing technological capabilities and skills needed in organisations particularly in relation to their professional and occupational programs.

As noted in this paper, one of the factors consistently identified by researchers as contributing to the growth gap particularly between developed and developing countries is the uneven diffusion of ICTs among regions. This has created a digital divide widening 
the development gap between countries which are able to benefit from the opportunities provided by ICT and those which are not. The need for policy reforms and investment in ICT innovation in Kenya is therefore clear and the current situation in university ICT education doesn't support this need. The lack of ICT educated Kenyans will have a potential impact on decreasing the country's economic competitiveness. Kenya has an opportunity to change the university education system in order for the universities to take a leading role in preparing ICT professionals. Overall, the country will reap substantial socio-economic benefits from increased investments in improving university education and developing strong ICT based-curriculum for a knowledge-based global economy.

There are also particularly compelling reasons for enhancing the overall quality of university education to contribute to a broader development of the society and the country's development goals as well as coordinated efforts between universities, the government and society to discuss the graduate unemployment problem. Enhancing quality is crucial in this era where the concept of knowledge economy supported by the Human Capital Theory has become influential in policy and public thinking despite its limitations. Graduates need to be well prepared for obtaining work and for making a positive contribution to their workplace and Kenyan society in general. The British Council (2014) suggested three key areas of work where universities must focus: Improving the quality of taught courses, enabling broader learning experiences for students and providing target employability input (informing students of career opportunities to enable them to reflect on their personal aptitudes and develop them further; skills enhancement programs and closer links with employers). What matters most is not just the numbers enrolled in universities, but the quality of education offered. A shift of conception is therefore urgently needed from access to quality or more precisely, towards access with quality since universities have a crucial role to play in fostering work skills, technological innovation, engagement and national development.

\section{References}

Aduda, D. (2016, May 23). Universities facing serious financial crisis. Daily Nation.

Aissaoui, N. (2017). ICT and growth gap between nations: Evidence from MENA region. E3 Journal of Business Management and Economics, 8(1): 026-037. doi: 10.18685/EJBME(8)1_EJBME-17-011

Arbo, P., \& Benneworth, P. (2007). Understanding the regional contribution of higher education institutions: A literature review. OECD Education Working Papers, 9(1). doi: $10.1787 / 161208155312$

Ayere, F., Odera, F., \& Agak, J. (2010). E-learning in secondary schools in Kenya: A case of the NEPAD E-schools. Educational Research and Reviews, 5(5): 218-223.

Retrieved from: http://www.academicjournals.org/journal/ERR/article-fulltextpdf/2F 928F 54044

Bailey, T., Cloate, N., \& Pundy, P. (2010). Universities and economic development in Africa: Case study: Kenya and University of Nairobi. Wynberg: HERANA/CHET.

Bloom, D. E., Canning, D., Chan, K.J. \& Luca, D.L. (2014). Higher education and economic growth in Africa. International Journal of African Higher Education, 1(1): 22-57. doi: 10.6017 /ijahe.v1i1.5643

Bloom, D.E., Hartley, M., \& Rosovsky, H. (2006). Beyond Private Gain: The Public Benefits of Higher Education. In J.J. Forest and P.G. Altbach (Eds), International Handbook of Higher Education V 1 (293-308). Dordrecht, the Netherlands: Springer.

Bogonko. S. N (1992). A History of Modern Education in Kenya (1895-1991). Nairobi: Evans Brothers (K) Limited.

Bonin, H. \& Hölzl, W. (2010). The Link between Job Creation, Innovation, Education and Training: An Assessment of Policies Pursued at EU Level. Directorate 
General for Internal Policies, Policy Department A: Economic and Scientific Policy. European Parliament: Brussels.

British Council (2016). Universities, employability and inclusive development: Repositioning higher education in Ghana, Kenya, Nigeria and South Africa. British Council.

British Council. (2014). Can Higher Education solve Africa's job crisis? Understanding graduate employability in Sub-Saharan Africa. Retrieved from: https://www.britishcouncil.org/sites/default/files/graduate_employability_in_s sa_final-web.pdf

Burtless, G. (2002). Can Supply-Side Policies Reduce Unemployment? Lessons from North America. Australian Economic Review, 35(1), 3-28.

Chege, M. (2015). Re-inventing Kenya's university: From a "Graduate-mill” to a development-oriented paradigm". International Journal of Educational Development, 44: 21-27. doi: 10.1016/j.ijedudev.2015.07.002

Commission for Higher Education. (2013). Institutional Audit Report 2013. Nairobi, Kenya: CUE.

Commission for University Education. (2017a). Accredited Universities in Kenya-March 2017.

Commission for University Education. (2017b). Summary Report of the Quality Audit Inspection of Universities Authorized to Operate in Kenya, 16 $6^{\text {th }}$ February 2017. Commission for University Education. Gigiri, Kenya.

Cuberes, D., \& Teignier, M. (2014). Gender inequality and economic growth: A critical review. Journal of International Development, 26(2): 260-276. doi: 10.1002/jid.2983

Easterly, W. (2014). The tyranny of experts: Economists, dictators, and the forgotten rights of the poor. Basic Books: New York.

De Giusti, G., \& Kambhampati, U.S. (2016). Women's work choices in Kenya: the role of social institutions and household gender attitudes. Feminist Economics, 22(2): 87113.

Ford, D. M. (2007). Technologizing Africa: On the bumpy information highway. Computers and Composition 24 (3): 302-3 16. doi: 10.1016/j.compcom.2007.05.005

Friedman, M., \& Friedman, R. (1980). Free to choose: A personal statement. New York: Harcourt, Brace and Jovanovich.

Government of the Republic of Kenya. (2007). Kenya Vision 2030. Nairobi: Government Printer.

Gillies, D. (2011). State education as high-yield investment: Human Capital Theory in European policy discourse. Journal of Pedagogy, 2(2): 224-245.

Gillies D. (2017). Human Capital Theory in Education. In M.A. Peters (Ed), Encyclopedia of Educational Philosophy and Theory (1-5). Springer: Singapore

Gyimah-Brempong, K., Paddison, O., \& Mitiku, W. (2006). Higher education and economic growth in Africa. The Journal of Development Studies 42(3): 509-529. doi: 10.1080/00220380600576490

Hirsch, W.Z., \& Weber, L.E. (1999). Preface. In W.Z. Hirsch \& L.E. Weber (Eds), Challenges Facing Higher Education at the Millennium. American Council on Education and Oryx Press: Phoenix, Arizona.

Institute of Economic Affairs. (2010). The Dynamics and Trends of Employment in Kenya, IEA Research Paper Series No. 1.

Jorgenson, D. W., \& Vu. K.M. (2016). The ICT revolution, world economic growth, and policy issues. Telecommunications Policy 40(5): 383-397. doi:

$10.1016 / \mathrm{j}$. telpol.2016.01.002

Kandiri, M. (2012). A survey on ICT access and use in Kenya secondary schools. Summit Strategies Ltd: Nairobi, Kenya. 
Kenya Bureau of Statistics. (2017). Statistical Abstracts. Retrieved from: https://www.knbs.or.ke/download/statistical-abstract-2017/

Kilonzo, S.M., (2011). Challenges of Autonomy in Higher Institutions of Learning in Kenya: Diluted Education? Retrieved from: https://www.isasociology.org/uploads/files/EBul-Mar20 11-Kilonzo.pdf

Kinoti, M. (2016, May 6). Looking forward to employment? Here's the reality check!”. Daily Nation.

Kiptalam, G. K., \& Rodrigues, A.J. (2010). Accessibility and utilization of ICTs among secondary school teachers in Kenya. ICT Works Organization. Nairobi, Kenya.

Kivati, G. (2017). The Role of Kenya’s Formal Higher Education in Sustainable Development Within the Context of Globalization. In L. Filho, L.W. Brandli, P. Castro, and J. Newman (Eds) Handbook of Theory and Practice of Sustainable Development in Higher Education, Volume 3 (17-33). Springer International Publishing.

Kruss, G., McGrath, S., Petersen, I.H., \& Gastrow, W. (2015). Higher education and economic development: The importance of building technological capabilities". International Journal of Educational Development ,43: 22-31. doi: 10.1016/j.ijedudev.2015.04.011

Lauglo, J. (2005). Vocationalised secondary education revisited. In Vocationalisation of secondary education revisited (pp. 3-49). Springer, Dordrecht.

Luo, Y., \& Bu, J. (2016). How valuable is information and communication technology? A study of emerging economy enterprises. Journal of World Business, 5 1(2): 200211. doi: $10.1016 /$ j.jwb.2015.06.001

Makinda, S. M. (2007). How Africa can benefit from knowledge. Futures, 39(8): 973-985. doi: 10.1016/j.futures.2007.03.004

Markovitz, I. L. (1977). Power and class in Africa: An introduction to change and conflict in African politics. New Jersey: Prentice Hall.

Maryska, M., Doucek, P., \& Kunstova, R. (2012). The Importance of ICT Sector and ICT University Education for the Economic Development. Procedia-Social and Behavioral Sciences, 55: 1060-1068. doi: 10.1016/j.sbspro.2012.09.598

Mathooko, F. M., \& Ogutu, M. (2015). Porter's five competitive forces framework and other factors that influence the choice of response strategies adopted by public universities in Kenya. International Journal of Educational Management, 29(3), 334354. doi: 10.1108/IJEM-12-2013-0187

Michubu, W. M., Nyerere, J.K., Kyalo, D.N. (2017). Learner Support Services and Quality of Education in Public Universities in Kenya. Asia Pacific Journal of Education, Arts and Sciences, 4(3): 19-24. Retrieved from: http://apjeas.apjmr.com/wpcontent/uploads/2017/06/APJEAS-2017.4.3.03.pdf

Mosha, H.J. (1986). The role of African universities in national developments. Higher Education, 15(1): 113-134. doi: 10.1007/BFo0 138096

Munene, I. (2016, February 17). Kenya's universities are in the grip of a quality crisis. The Conversation. Retrieved from: http://theconversation.com/kenyasuniversities-arein-the-grip-of-a-quality-crisis-54664

Mungai, C. (2015, March 19). Students give it their best, but in the end, employers find they are still not good enough. Mail Guardian Africa.

Mwiria, K., \& Nyukuri, M.S. (1994) The Management of Double Intakes: a case study of Kenyatta University. Paris, Unesco (II EP).

Ndirangu, M., \& M. O. Udoto. 2011. "Quality of learning facilities and learning environment: Challenges for teaching and learning in Kenya's public universities". Quality Assurance in Education 19(3): 208-223. doi: 10.1108/09684881111158036 
Ngome, C. (2003). Kenya. In D. Teferra \& P. Altbach (Eds.), African higher education: An international reference (pp. 359-370) Bloomington: Indiana University Press

Ngure, S. W. (2013). Where to Vocational Education in Kenya? Is Analysing Training and Development Needs the Answer to the Challenges in this Sector?. Journal of Education and Vocational Research, 4(6), 193-204.

Nyangau, J. Z. (2014). Higher education as an instrument of economic growth in Kenya. FIRE: Forum for International Research in Education, 1(1): 7-25.

Ndung'u, N., Thugge, K., \& Otieno, O. (2011). Unlocking the Future Potential for Kenya: The vision 2030. Nairobi: Government Printers.

NESC. (2007). Kenya Vision 2030: A globally competitive and prosperous Kenya. National Economic and Social Council of Kenya.

Nesoba, D. (2012). Youth Unemployment Crisis Continues, Millions of College Grads Flood Unemployment Lines. Global Press Journal.

Odhiambo, G. (2011). Higher education quality in Kenya: a critical reflection of key challenges. Quality in Higher Education, 17(3): 299-315. doi: $10.1080 / 13538322.2011 .614472$

Odhiambo, G. (2014). Quality assurance for public higher education: context, strategies and challenges in Kenya. Higher Education Research \& Development, 33(5): 978991. doi: 10.1080/07294360.2014.890578

Odhiambo, G. (2016). Higher education in Kenya: an assessment of current responses to the imperative of widening access. Journal of Higher Education Policy and Management, 38(2): 196-211. doi: 10.1080/1360080X.2016.1150551

Oduol, J. B. A., Mithöfer, D., Place, F., Nang'ole, E., Olwande, J., Kirimi, L., \& Mathenge, M. (2017). Women's participation in high value agricultural commodity chains in Kenya: Strategies for closing the gender gap. Journal of rural studies, 50: 228-239.

Oketch, M., McCowan, T., \& Schendel, R. (2014). The impact of tertiary education on development: A rigorous literature review. London: Department for International Development.

Omolo, J. (2012). Touth Employment in Kenya: Analysis of Labour Market and Policy Interventions. FES Kenya Occasional paper, no 1. Nairobi: Friedrich Ebert Stiftung.

Orji, E.K., \& Maekae, J. (2013). The Role of Education in National Development: Nigerian Experience. European Scientific Journal, 9(28): 312-320.

Pillay, P. (2011). Higher education and economic development: Literature review. Centre for Higher Education Transformation. Cape Town.

Republic of Kenya. (1964). Kenya Education Commission Report. Nairobi: Government Printer.

Republic of Kenya. (1969). National Development Plan, 1970-1994. Nairobi: Government Printer.

Republic of Kenya. (2005). Kenya Education Sector Support programme (KESP) 2005-2010. Nairobi: Government Printer.

Republic of Kenya. (2006). Transformation of higher education and training in Kenya to secure Kenya's development in the knowledge economy: report of the Public Universities Inspection Board. Nairobi: Government Printer.

Republic of Kenya. (2007). Report of the task force for the development of the national strategy for university education (The Wandiga Report). Nairobi, Kenya: Government Printer.

Rhoades, G., \& Slaughter, S. (1997). Academic capitalism, managed professionals, and supply-side higher education. Social Text, (51), 9-38. 
Sanou, B. (2011). The Role of ICT in Advancing Growth in Least Developed Countries: Trends, Challenges and Opportunities. ITU-Telecommunication Development Bureau.

Stromquist, N. P. (2017). Research Twenty years later: International efforts to protect the rights. Education International.

Szirmai, A. (2015). Socio-economic development. Cambridge, UK: Cambridge University Press.

Tarus, J. (2011). Adoption of e-learning to support teaching and learning in Moi University. (Unpublished Master of Philosophy Thesis), Moi University, Kenya.

Tarus, J. K., Gichoya, D., \& Muumbo, A. (2015). Challenges of implementing e-learning in Kenya: A case of Kenyan public universities. The International Review of Research in Open and Distributed Learning, 16(1).

Thomas S. L. \& Heck, R.H. (2001). Analysis of large-scale secondary data in higher education research: Potential perils associated with complex sampling designs. Research in higher education, 42(5): 517-540.

Tilak, J. B. G. (2005). Are we marching towards Laissez-faireism in Higher Education Development? Journal of International Cooperation in Education, 8(1): 153-165.

Todaro,.P. M., \& Smith, C.S. (2015). Economic Development (12 $2^{\text {th }}$ ed) England: Pearson Education Limited.

Uetela, P. (2017). Higher Education and Development in Africa. Maputo, Mozambique: Palgrave McMillan.

UNDP (United Nations Development Programme). (2001). Information CommunicationsUnited Nations Information Service. (2000, August 3). Information technology should be used to tap knowledge from greatest universities to bring learning to all, Kofi Annan says. Press Release No: UNIS/SG/2625.

Wanzala O. (2015). "World Bank raises concern on quality of Kenya's graduates". Daily Nation, October 1.

Wanzala, O. (2016, January 21). CUE revokes degrees awarded to five students by Kisii University. Daily Nation.

Wanzala, O. (2017, April 6). Varsities and employers team up to resolve skills mismatch". Daily Nation.

Wanzala, O. (2018). Proposal seeks to save private universities facing cash crisis. Press reader.

Wesangula, D. (2014, June 7). Only half of university graduates in Kenya are ready for job market, study says. The Standard.

West, J. (2000). Higher education and employment: opportunities and limitations in the formation of skills in a mass higher education system. Journal of Vocational Education and Training, 52(4), 573-588.

World Bank. (2014). Touth Employment in Sub-Saharan Africa: Africa Development forum. Washington: World Bank.

World Bank. (2016). Kenya Economic Update, March 2016, Edition Number 13.

Zaman, M., Shamim, R. \& Clement, K. (2011). Trends and issues to integrate ICT in teaching and learning for the future world of education. International Journal of Engineering \& Technology, $11(3)$ : 114-119.

\section{About the Author}

George Odhiambo, $\mathrm{PhD}$, has extensive research expertise and a continuing active interest in the areas of leadership in organisations, organisational change and culture, school effectiveness and improvement, staff development, quality assurance for education; staff/teacher appraisal and Higher Education policy. He is a graduate of the University of 
Stirling, Scotland, University of Oxford, England and University of New England, Australia. He is a regular contributor to African university policy debate on issues surrounding the assessment of research, teaching performance and leadership challenges. He recently taught and held visiting fellowship position at the School of Education, University of Leeds, UK. 